\title{
Diallel cross analysis of plesiomorphic traits in Triticum aestivum L. genotypes
}

\author{
M. Shehzad', S.B. Hussain ${ }^{1}$, M.K. Qureshi' ${ }^{1}$, M. Akbar'1, M. Javed', \\ H.M. Imran ${ }^{1}$ and S.A. Manzoor ${ }^{2}$ \\ 'Department of Plant Breeding and Genetics, \\ Faculty of Agricultural Sciences and Technology, Bahauddin Zakariya University, \\ Multan, Punjab, Pakistan \\ ${ }^{2}$ Department of Forestry and Range Management, \\ Faculty of Agricultural Sciences and Technology, Bahauddin Zakariya University, \\ Multan, Punjab, Pakistan \\ Corresponding author: S.A. Manzoor \\ E-mail: amir.kzd@gmail.com \\ Genet. Mol. Res. 14 (4): 13485-13495 (2015) \\ Received February 27, 2015 \\ Accepted July 22, 2015 \\ Published October 28, 2015 \\ DOI http://dx.doi.org/10.4238/2015.October.28.9
}

ABSTRACT. We conducted a $5 \times 5$ complete diallel cross experiment in bread wheat (Triticum aestivum) with the genotypes 6309, Chkwal-50, Dhrabi, Bhkhar-02, and FS-08. Our objective was to evaluate the type of gene action and the general and specific combining abilities required for various morphological traits in wheat. The results of analysis of variance revealed highly significant differences among genotypes for all the investigated traits. The results of joint regression analysis showed that the data for all the investigated traits fitted a simple additive dominance model. Graphical representation of variance and covariance suggested that most of the investigated traits were controlled by overdominance gene action. However, the peduncle length and plant height were controlled by additive gene action. Variety 6309 carried the highest number of dominant genes for the number of spikelets per spike, number of tillers per plant, plant height, number of fertile tillers per plant, and grain yield per plant. 
Chakwal-50 carried the highest number of recessive genes for grain yield per plant, number of tillers per plant, number of grains per spike, number of fertile tillers per plant, and plant height. Chakwal-50 and 6309 were the best general combiners for number of spikelets per spike, number of grains per spike, grain yield per plant, 1000-grain weight, number of fertile tillers per plant, and number of tillers per plant. On other hand, 6309 performed well in specific crosses with Chakwal-50, FS-08, and Bhakhar-02 for spike length and number of tillers per plant.

Key words: Diallel; Gene action; Genotypes; Morphological traits

\section{INTRODUCTION}

Bread wheat (Triticum aestivum L.) is a self-pollinated crop that belongs to the family Gramineae (also known as Poaceae). It serves as an essential food source in most countries of the world. Wheat straw is also important as fodder. During 2011-2012, agriculture growth in Pakistan increased by approximately 3.1\%, up from 2.4\% during 2010-2011 (GOP, 2012). Pakistan is self-sufficient regarding its wheat crop because of its suitable geographical location, particularly the fertile land of Punjab Province. The objective of breeders is to enhance yield; however, this is complex because yield is controlled by polygenic traits. The diallel analysis formulated by Hayman (1954) and Jinks (1954) constitutes a relatively authentic mechanism for investigating the type of gene action required for the development of important morphological characters. Conventional breeding through crossing superior lines with each other generates a relatively small gene pool (Appels and Lagudah, 1990; Valkoun, 2001; Hajjar and Hodgkin, 2007; Feuillet et al., 2008). The missing genes can be restored and exploited to improve wheat through crosses with wild ancestors. Breeding programs are starting to show the benefits of incorporating wild genes into adapted lines (Warburton et al., 2006). In the present study, we evaluated the type of gene action required for various morphological traits in wheat. In addition, we examined the general and specific combining abilities for yield and yield-contributing traits.

\section{MATERIAL AND METHODS}

We conducted our study during 2011-2012 at the experimental farm of the Department of Plant Breeding and Genetics, Faculty of Agricultural Sciences and Technology, Bahauddin Zakariya University, Multan, Pakistan. We used five wheat cultivars-6309, Chkwal-50, Dhrabi, Bhkhar-02, and FS-08 -as parents. We sowed these cultivars in the field on December 1, 2011. We hybridized the cultivars using the $5 \times 5$ complete diallel cross method. The female plants were emasculated by hand and were covered with buttered paper bags during the crossing period to avoid contamination of the genetic material. The emasculated ears were carefully pollinated by hand to obtain direct and indirect $F_{1}$ crosses. All other agronomic practices were applied according to conventional field practices. At maturity, crossed spikes were harvested and individually threshed with their parents. The $F_{0}$ seeds from all crosses and their parents were sown on November 25, 2012. The parental genotypes and 20 crosses were implanted using RCBD with three replications. Each entry of parents and crosses comprised a four-row plot (length, $4.57 \mathrm{~m}$ ). The row-to-row and plant-to-plant distances were 0.3 and $0.15 \mathrm{~m}$, respectively. All cultural practices were applied 
uniformly from sowing to harvesting time. At maturity, 10 plants per replication were randomly selected and tagged, and the data from each cross and parent were individually recorded. The following traits were considered: 1000-grain weight; number of fertile tillers per plant; grain yield per plant; number of grains per spike; peduncle length; plant height; spike length; number of spikelets per spike; and number of tillers per plant. After compilation, all data were analyzed using the full diallel analysis method proposed by Hayman (1954) and Jinks (1954). Analysis of variance was conducted to determine significant differences in plant characters between genotypes (Steel et al., 1997).

\section{RESULTS AND DISCUSSION}

The results of joint regression analysis suggested that all the investigated traits were appropriate for genetic analysis (Table 1). The results of analysis of variance revealed highly significant differences between genotypes for all the investigated traits (Table 2). The regression line cut-off point for the 1000-grain weight was located below the origin on the covariance (Wr) axis, implying that this trait was controlled by overdominance gene action (Figure 1). Epistasis was absent in this character. Our results are in agreement with previous findings (Shekhawat et al., 2000; Kashif and Khaliq, 2003; Gurmani et al., 2007). The arrange point of array showed that Dhrabi was located closest to the origin and had the highest number of dominant genes. On the other hand, Bhakhar-02 was located furthest from the origin and had the highest number of recessive genes (Figure 1). Chakwal-50 had a higher mean value (46.28) than the other investigated genotypes, and therefore this genotype was a better universal combiner (Table 3). A cross between 6309 and FS-08 had a higher mean value (51.43) than the other investigated cross combinations, indicating a greater specific combining ability (SCA).

\begin{tabular}{|c|c|c|}
\hline Serial No. & Trait & Coefficient of regression \\
\hline 1 & 1000-grain weight & $0.87 \pm 0.88$ \\
\hline 2 & Number of fertile tillers per plant & $0.84 \pm 0.43$ \\
\hline 3 & Grain yield per plant & $0.75 \pm 0.29$ \\
\hline 4 & Number of grains per spike & $1.01 \pm 0.20$ \\
\hline 5 & Peduncle length & $1.00 \pm 0.13$ \\
\hline 6 & Plant height & $1.00 \pm 0.12$ \\
\hline 7 & Spike length & $0.86 \pm 0.22$ \\
\hline 8 & Number of spikelets per spike & $0.80 \pm 2.77$ \\
\hline 9 & Number of tillers per plant & $0.80 \pm 0.52$ \\
\hline
\end{tabular}

All results were acceptable for use in genetic analysis. Calculated b value close to zero and not equal to unity.

\begin{tabular}{|c|c|c|c|c|c|c|c|c|c|c|}
\hline $\begin{array}{l}\text { Source } \\
\text { of variation }\end{array}$ & $\begin{array}{l}\text { Degrees } \\
\text { of freedom }\end{array}$ & $\begin{array}{c}\text { 1000-grain } \\
\text { weight }\end{array}$ & $\begin{array}{l}\text { No. of fertile } \\
\text { tillers per plant }\end{array}$ & $\begin{array}{c}\text { Grain yield } \\
\text { per plant }\end{array}$ & $\begin{array}{l}\text { No. of grains } \\
\text { per spike }\end{array}$ & $\begin{array}{l}\text { Peduncle } \\
\text { length }\end{array}$ & $\begin{array}{l}\text { Plant } \\
\text { height }\end{array}$ & $\begin{array}{l}\text { Spike } \\
\text { length }\end{array}$ & $\begin{array}{l}\text { No. of spikelets } \\
\text { per spike }\end{array}$ & $\begin{array}{c}\text { No. of tillers } \\
\text { per plant }\end{array}$ \\
\hline \multirow[t]{2}{*}{ Replication } & 2 & 1.40 & 2.86 & 2.38 & 5.66 & 0.58 & 0.81 & 1.90 & 0.78 & 0.79 \\
\hline & & $0.15^{\mathrm{NS}}$ & $9.22^{\star *}$ & $6.50^{* *}$ & $0.579^{\mathrm{NS}}$ & $0.198^{\mathrm{NS}}$ & $0.16^{\mathrm{NS}}$ & $7.03^{\text {** }}$ & $2.51^{\mathrm{NS}}$ & $0.96^{\mathrm{NS}}$ \\
\hline \multirow[t]{2}{*}{ Genotype } & 24 & 65.06 & 1.45 & 95.64 & 237.49 & 23.32 & 57.10 & 3.46 & 5.34 & 2.03 \\
\hline & & $7.31^{\star \star}$ & $4.67^{\star \star}$ & $14.71^{* *}$ & $24.30^{\star *}$ & $7.98^{\star \star}$ & $11.87^{\star *}$ & $12.81^{* *}$ & $17.22^{\star \star}$ & $2.47^{\star *}$ \\
\hline Error & 48 & 8.89 & 0.31 & 6.50 & 9.77 & 2.92 & 4.81 & 0.27 & 0.31 & 0.82 \\
\hline
\end{tabular}

${ }^{* *}$ Highly significant; ${ }^{\mathrm{NS}}$ not significant. 


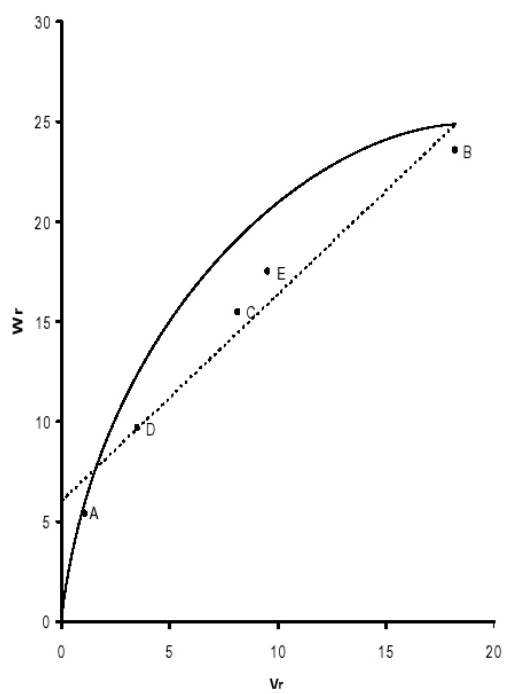

Figure 1. Graphical representation of variance (Wr) and covariance (Vr) for 1000-grain weight. Genotypes 6309 (A), Chkwal-50 (B), Dhrabi (C), Bhkhar-02 (D), and FS-08 (E).

Regarding the numbers of fertile tillers per plant, variety 6309 was located closest to the origin and had the highest number of dominant genes. On the other hand, Chakwal-50 was located furthest from the origin and had the highest number of recessive genes (Figure 2). Chakwal-50 had a higher mean value (12.01) than the other investigated genotypes, and therefore this genotype was a better universal combiner (Table 3). A cross between Dhrabi and FS-08 had a higher mean value (12.23) than the other investigated cross combinations, indicating a greater SCA. Our results are consistent with previous findings (Sharma and Ahmad, 1980; Rabbani et al., 2009).

Regarding the grain yield per plant, variety 6309 was located closest to the origin and had the highest number of dominant genes. On the other hand, FS-08 was located furthest from the origin and had the highest number of recessive genes (Figure 3). Variety FS-08 had a higher mean value (28.90) than the other investigated genotypes, and therefore this genotype was a better universal combiner. A cross between 6309 and Chakwal-50 had a higher mean value (32.32) than the other investigated cross combinations, indicating a greater SCA (Table 3). Our results are in accordance with previous findings (Shekhawat et al., 2000; Kashif and Khaliq, 2003).

Regarding the number of grains per spike, Dhrabi was located closest to the origin and had the highest number of dominant genes. On the other hand, Chakwal-50 was located furthest from the origin and had the highest number of recessive genes (Figure 4). Variety 6309 had a higher mean value (68.11) than the other investigated genotypes, and therefore this genotype was a better universal combiner (Table 3). A cross between 6309 and Chakwal-50 had a higher mean value (72.40) than the other investigated cross combinations, indicating a greater SCA. Our results are in agreement with previous findings (Shahzad et al., 1998; Asif et al., 1999; Gurmani et al., 2007).

Regarding the peduncle length, Chakwal-50 was located closest to the origin and had the highest number of dominant genes. On the other hand, Dhrabi was located furthest from the origin and had the highest number of recessive genes (Figure 5). Bhakhar-02 had a higher mean value 
(38.59) than the other investigated genotypes, and therefore this genotype was a better universal combiner (Table 3). A cross between Bhakhar-02 and Dhrabi had a higher mean value (40.28) than the other investigated cross combinations, indicating a greater SCA. Our results are consistent with previous findings (Khan et al., 2000; Khan and Habib, 2003).

\begin{tabular}{|c|c|c|c|c|c|c|}
\hline Trait & Genotype & 6309 & Chakwal-50 & Dhrabi & Bhakhar-02 & FS-08 \\
\hline \multirow[t]{7}{*}{1000 -grain weight } & 6309 & 39.20 & 47.15 & 42.82 & 42.32 & 51.43 \\
\hline & Chakwal-50 & 47.15 & 40.23 & 47.37 & 49.75 & 46.88 \\
\hline & Dhrabi & 42.82 & 47.37 & 43.43 & 39.93 & 39.00 \\
\hline & Bhakhar-02 & 42.32 & 49.75 & 39.93 & 52.43 & 46.57 \\
\hline & FS-08 & 51.43 & 46.88 & 39.00 & 46.57 & 46.00 \\
\hline & Total & 222.92 & 231.38 & 212.55 & 231.00 & 229.88 \\
\hline & Mean & 44.58 & 46.28 & 42.51 & 46.20 & 45.98 \\
\hline \multirow[t]{7}{*}{ Number of fertile tillers per plant } & 6309 & 11.87 & 11.93 & 12.00 & 12.05 & 11.72 \\
\hline & Chakwal-50 & 11.93 & 13.67 & 11.17 & 11.52 & 11.78 \\
\hline & Dhrabi & 12.00 & 11.17 & 12.00 & 10.88 & 12.23 \\
\hline & Bhakhar-02 & 12.05 & 11.52 & 10.88 & 11.63 & 11.45 \\
\hline & FS-08 & 11.72 & 11.78 & 12.23 & 11.43 & 11.00 \\
\hline & Total & 59.57 & 60.07 & 58.28 & 57.51 & 58.18 \\
\hline & Mean & 11.91 & 12.01 & 11.66 & 11.50 & 11.63 \\
\hline \multirow{7}{*}{ Grain yield per plant } & 6309 & 32.32 & 26.48 & 30.63 & 28.67 & 26.40 \\
\hline & Chakwal-50 & 19.43 & 28.17 & 24.18 & 25.57 & 32.32 \\
\hline & Dhrabi & 28.17 & 32.27 & 22.47 & 20.15 & 26.48 \\
\hline & Bhakhar-02 & 24.18 & 22.47 & 25.40 & 22.15 & 30.63 \\
\hline & FS-08 & 25.57 & 20.15 & 22.15 & 16.57 & 28.67 \\
\hline & Total & 129.67 & 129.54 & 124.83 & 113.11 & 144.50 \\
\hline & Mean & 25.93 & 24.11 & 24.97 & 22.62 & 28.90 \\
\hline \multirow[t]{7}{*}{ Number of grains per spike } & 6309 & 58.67 & 72.40 & 68.00 & 72.17 & 69.93 \\
\hline & Chakwal-50 & 72.40 & 48.43 & 69.52 & 58.77 & 61.67 \\
\hline & Dhrabi & 68.00 & 69.52 & 60.77 & 59.90 & 67.22 \\
\hline & Bhakhar-02 & 72.17 & 58.77 & 59.90 & 50.57 & 59.22 \\
\hline & FS-08 & 69.33 & 61.67 & 67.62 & 59.22 & 48.00 \\
\hline & Total & 340.57 & 310.79 & 325.81 & 300.63 & 306.04 \\
\hline & Mean & 68.11 & 62.16 & 65.16 & 60.12 & 61.17 \\
\hline \multirow[t]{7}{*}{ Peduncle length } & 6309 & 31.77 & 34.78 & 33.62 & 35.52 & 34.52 \\
\hline & Chakwal-50 & 34.78 & 36.53 & 37.50 & 37.33 & 36.10 \\
\hline & Dhrabi & 33.62 & 37.50 & 39.97 & 40.28 & 38.35 \\
\hline & Bhakhar-02 & 35.52 & 37.33 & 40.28 & 41.23 & 38.57 \\
\hline & FS-08 & 34.52 & 36.10 & 38.35 & 38.57 & 35.77 \\
\hline & Total & 170.21 & 182.24 & 189.72 & 192.93 & 183.31 \\
\hline & Mean & 34.04 & 36.45 & 37.94 & 38.59 & 36.66 \\
\hline \multirow[t]{7}{*}{ Plant height } & 6309 & 96.63 & 94.88 & 96.15 & 97.40 & 96.82 \\
\hline & Chakwal-50 & 94.88 & 85.00 & 91.43 & 95.85 & 91.02 \\
\hline & Dhrabi & 96.15 & 91.43 & 95.67 & 99.35 & 94.63 \\
\hline & Bhakhar-02 & 97.40 & 95.85 & 99.35 & 100.63 & 99.22 \\
\hline & FS-08 & 96.82 & 91.02 & 94.63 & 99.22 & 96.90 \\
\hline & Total & 481.88 & 458.18 & 477.23 & 492.45 & 478.59 \\
\hline & Mean & 96.38 & 91.64 & 95.45 & 98.49 & 95.72 \\
\hline \multirow[t]{7}{*}{ Spike length } & 6309 & 10.33 & 11.95 & 12.23 & 13.02 & 12.58 \\
\hline & Chakwal-50 & 11.95 & 10.33 & 13.38 & 11.83 & 12.03 \\
\hline & Dhrabi & 12.23 & 13.38 & 11.67 & 12.70 & 13.03 \\
\hline & Bhakhar-02 & 13.02 & 11.83 & 12.70 & 10.33 & 12.67 \\
\hline & FS-08 & 12.58 & 12.03 & 13.03 & 12.67 & 10.03 \\
\hline & Total & 60.11 & 59.52 & 63.01 & 60.55 & 60.34 \\
\hline & Mean & 12.02 & 11.91 & 12.60 & 12.11 & 12.07 \\
\hline \multirow[t]{7}{*}{ Number of spikelets per spike } & 6309 & 19.63 & 20.73 & 20.28 & 20.00 & 19.05 \\
\hline & Chakwal-50 & 20.73 & 18.10 & 21.12 & 19.60 & 19.02 \\
\hline & Dhrabi & 20.28 & 21.12 & 19.33 & 19.47 & 19.28 \\
\hline & Bhakhar-02 & 20.00 & 19.60 & 19.47 & 16.10 & 19.15 \\
\hline & FS- 08 & 19.05 & 19.02 & 19.28 & 19.15 & 16.77 \\
\hline & Total & 99.69 & 98.57 & 99.48 & 94.32 & 93.27 \\
\hline & Mean & 19.94 & 19.71 & 19.90 & 18.86 & 18.65 \\
\hline \multirow[t]{7}{*}{ Number of tillers per plant } & 6309 & 12.00 & 12.15 & 12.20 & 12.17 & 11.72 \\
\hline & Chakwal-50 & 12.15 & 13.77 & 11.17 & 11.62 & 11.88 \\
\hline & Dhrabi & 12.20 & 11.17 & 12.00 & 10.88 & 12.33 \\
\hline & Bhakhar-02 & 12.17 & 11.62 & 10.88 & 11.63 & 10.82 \\
\hline & FS-08 & 11.72 & 11.88 & 12.33 & 10.82 & 11.00 \\
\hline & Total & 60.24 & 60.59 & 58.58 & 57.12 & 57.75 \\
\hline & Mean & 12.05 & 12.12 & 11.72 & 11.42 & 11.55 \\
\hline
\end{tabular}




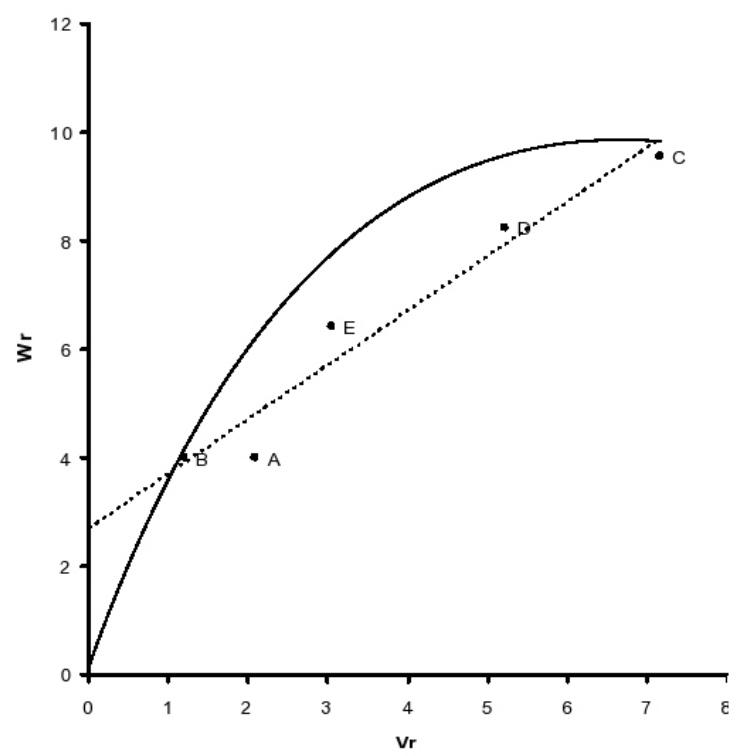

Figure 2. Graphical representation of variance $(\mathrm{Wr})$ and covariance $(\mathrm{Vr})$ for number of fertile tillers per plant. Genotypes 6309 (A), Chkwal-50 (B), Dhrabi (C), Bhkhar-02 (D), and FS-08 (E).

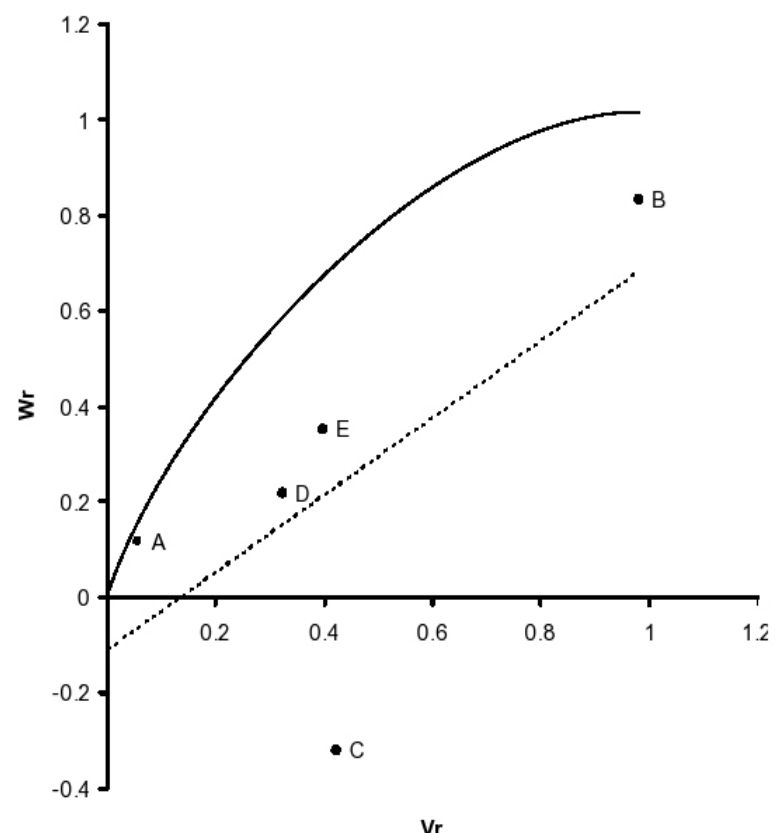

Figure 3. Graphical representation of variance $(\mathrm{Wr})$ and covariance $(\mathrm{Vr})$ for grain yield per plant. Genotypes 6309 (A), Chkwal-50 (B), Dhrabi (C), Bhkhar-02 (D), and FS-08 (E). 


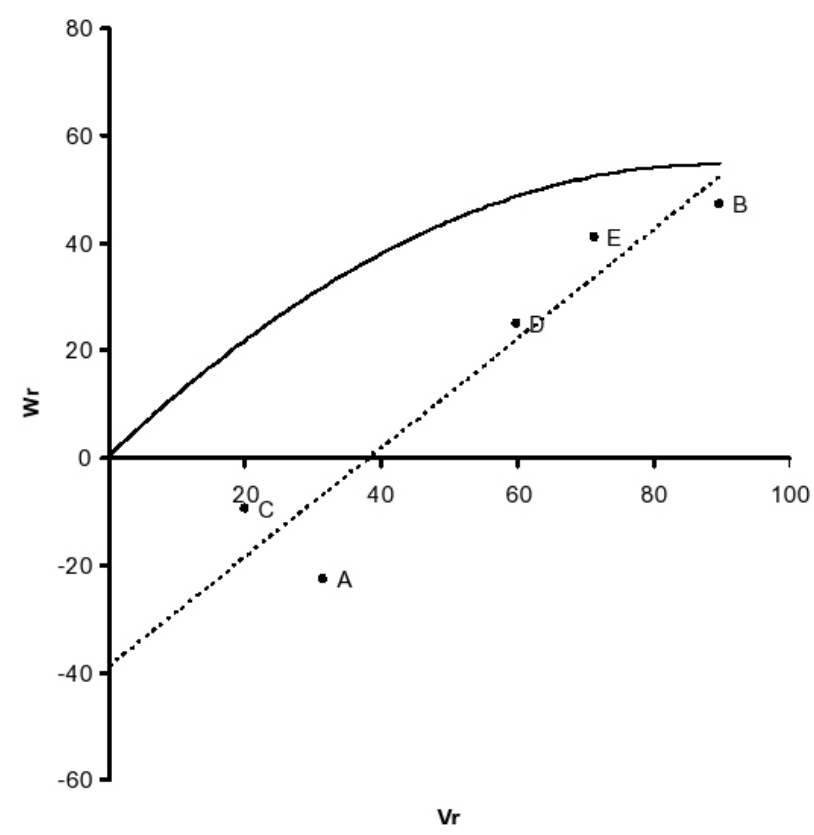

Figure 4. Graphical representation of variance $(\mathrm{Wr})$ and covariance $(\mathrm{Vr})$ for number of grains per spike. Genotypes 6309 (A), Chkwal-50 (B), Dhrabi (C), Bhkhar-02 (D), and FS-08 (E).

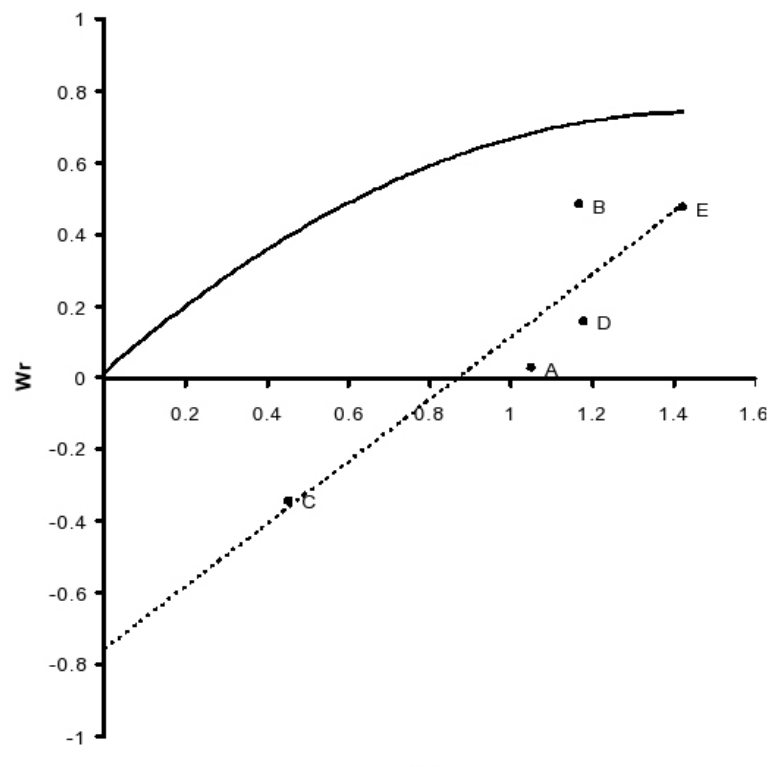

vr

Figure 5. Graphical representation of variance $(\mathrm{Wr})$ and covariance $(\mathrm{Vr})$ for peduncle length. Genotypes 6309 (A), Chkwal-50 (B), Dhrabi (C), Bhkhar-02 (D), and FS-08 (E). 
Regarding the plant height, variety 6309 was located closest to the origin and had the highest number of dominant genes. On the other hand, Chakwal-50 was located furthest from the origin and had the highest number of recessive genes (Figure 6). Bhakhar-02 had a higher mean value (98.59) than the other investigated genotypes, and therefore this genotype was a better universal combiner (Table 3). A cross between Bhakhar-02 and Dhrabi had a higher mean value (99.35) than the other investigated cross combinations, indicating a greater SCA. Our results are in accordance with previous findings (Arshad and Chowdhry, 2003; Kashif and Khaliq, 2003).

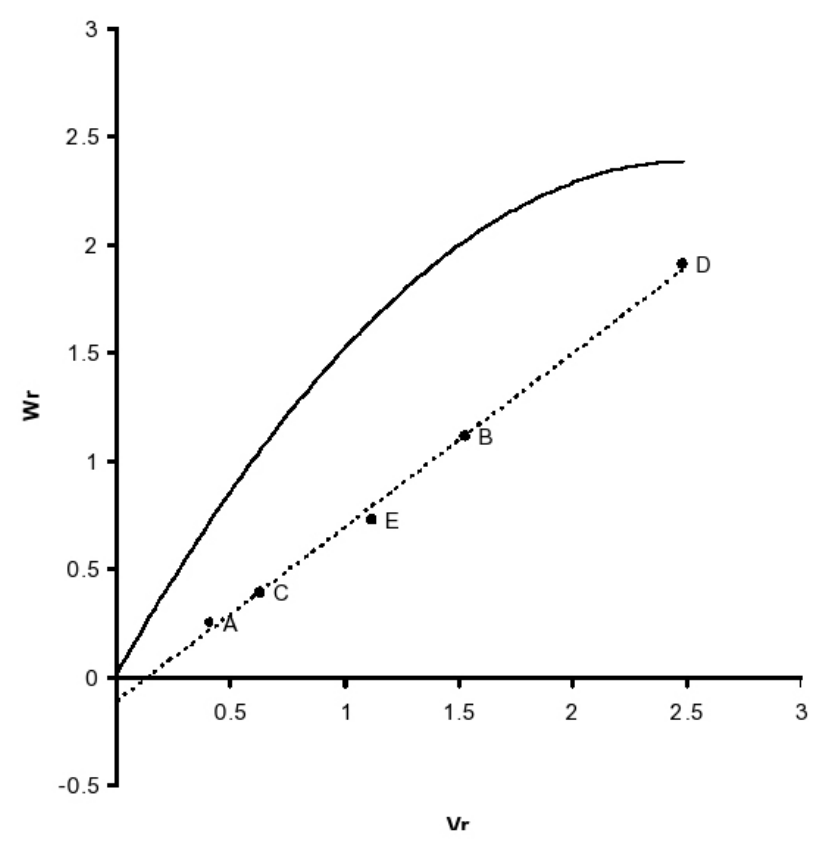

Figure 6. Graphical representation of variance (Wr) and covariance (Vr) for plant height. Genotypes 6309 (A), Chkwal-50 (B), Dhrabi (C), Bhkhar-02 (D), and FS-08 (E).

Regarding the spike length, Dhrabi was located closest to the origin and had the highest number of dominant genes. On the other hand, $\mathrm{FH}-08$ was located furthest from the origin and had the highest number of recessive genes (Figure 7). Dhrabi had a higher mean value (12.60) than the other investigated genotypes, and therefore this genotype was a better universal combiner (Table 3). A cross between Chakwal-50 and Dhrabi had a higher mean value (13.38) than the other investigated cross combinations, indicating a greater SCA. Our results are in agreement with previous findings (Ali et al., 1999; Gurmani et al., 2007).

Regarding the number of spikelets per spike, variety 6309 was located closest to the origin and had the highest number of dominant genes. On the other hand, Bhakhar-02 was located furthest from the origin and had the highest number of recessive genes (Figure 8). Variety 6309 had a higher mean value (19.94) than the other investigated genotypes, and therefore this genotype was a better universal combiner (Table 3). A cross between Dhrabi and Chakwal-50 had a higher mean value (21.12) than the other investigated cross combinations, indicating a greater SCA. Our results are consistent with previous findings (Khan et al., 1992; Gurmani et al., 2007). 


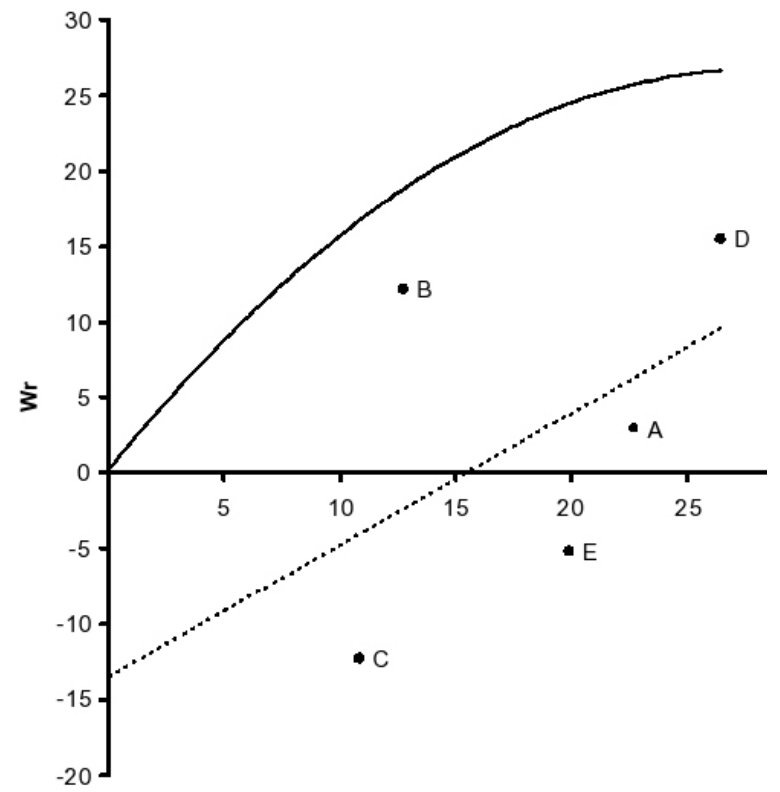

Figure 7. Graphical representation of variance $(\mathrm{Wr})$ and covariance $(\mathrm{Vr})$ for spike length. Genotypes 6309 (A), Chkwal-50 (B), Dhrabi (C), Bhkhar-02 (D), and FS-08 (E).

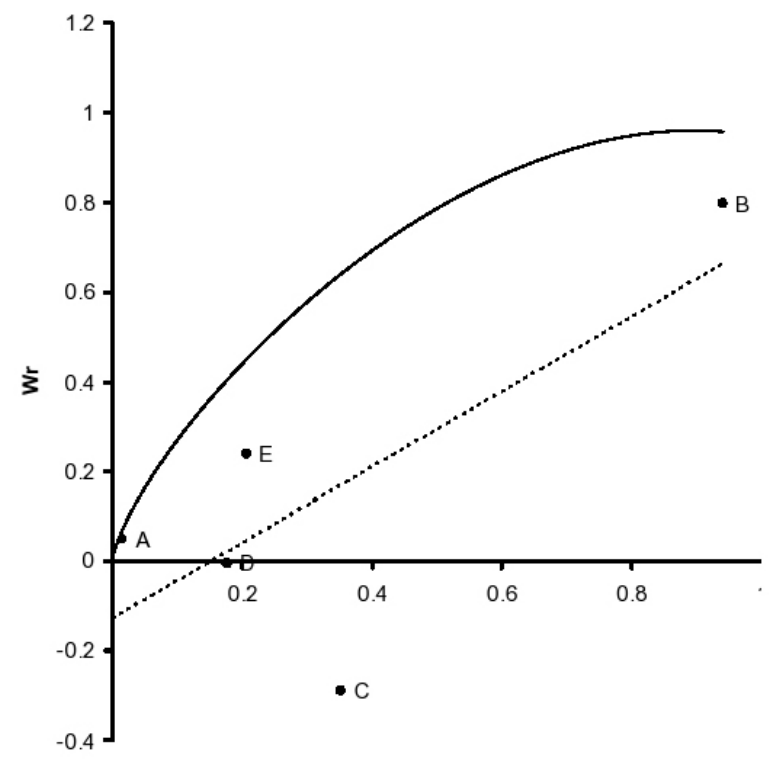

$\mathrm{Vr}$

Figure 8. Graphical representation of variance $(\mathrm{Wr})$ and covariance $(\mathrm{Vr})$ for number of spikelets per spike. Genotypes 6309 (A), Chkwal-50 (B), Dhrabi (C), Bhkhar-02 (D), and FS-08 (E). 
Regarding the number of tillers per plant, variety 6309 was located closest to the origin and had the highest number of dominant genes. On the other hand, Chakwal-50 was located furthest from the origin and had the highest number of recessive genes (Figure 9). Chakwal-50 had a higher mean value (12.12) than the other investigated genotypes, and therefore this genotype was a better universal combiner (Table 3). A cross between FS-08 and Dhrabi had a higher mean value (12.33) than the other investigated cross combinations, indicating a greater SCA. Our results are in accordance with previous findings (Munir, 1997; Shekhawat et al., 2000).

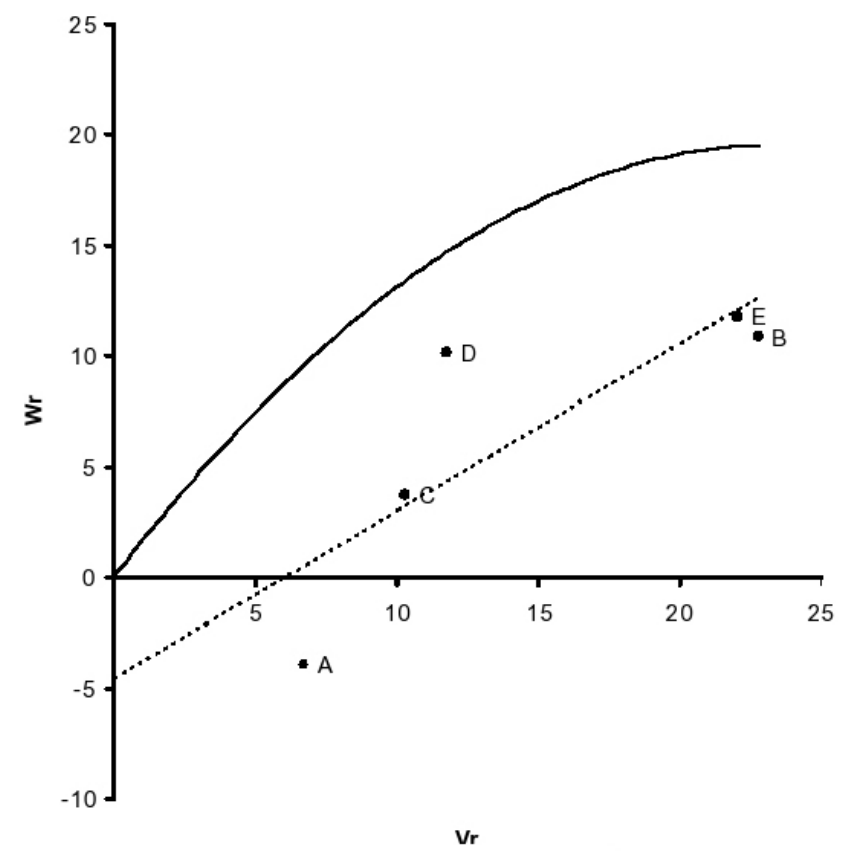

Figure 9. Graphical representation of variance $(\mathrm{Wr})$ and covariance $(\mathrm{Vr})$ for number of tillers per plant. Genotypes 6309 (A), Chkwal-50 (B), Dhrabi (C), Bhkhar-02 (D), and FS-08 (E).

\section{CONCLUSION}

In the present study, we observed that morphological traits of wheat such as 1000-grain weight, number of fertile tillers per plant, grain yield per plant, number of grains per spike, peduncle length, spike length, number of spikelets per spike, and number of tillers per plant were generally controlled by overdominance gene action. However, some traits were controlled by additive gene action. Non-allelic interaction was absent in these traits. Based on our present findings, we propose that breeders should use the varieties Dhrabi, FS-08, and Bhakhar-02 to improve morphological traits and the varieties 6309 and Chakwal-50 to enhance yield characters.

\section{Conflicts of interest}

The authors declare no conflict of interest. 


\section{REFERENCES}

Ali Z, Khan AS and Khan TM (1999). Gene action for plant height, grain yield and its component spring wheat. Pakistan J. Biol. Sci. 2: 1561-1563.

Appels R and Lagudah ES (1990). Manipulation of chromosomal segments from wild wheat for the improvement of bread wheat. Aust. J. Plant Physiol. 17: 253-266.

Arshad M and Chowdhry MA (2003). Genetic behavior of wheat under irrigated and drought stress environment. Asian J. Plant Sci. 2: 58-64.

Asif M, Khaliq I, Chowdhry MA and Salam A (1999). Genetic mechanisms for some spike characteristics and grain yield in bread wheat. Pakistan J. Biol. Sci. 2: 948-951.

Feuillet C, Langridge P and Waugh R (2008). Cereal breeding takes a walk on the wild side. Trends Genet. 24: 24-32.

Government of Pakistan (GOP) (2012). Pakistan Bureau of Statistics Population 2011. Islamabad.

Gurmani RR, Khan SJ, Saqib ZA, Khan R, et al. (2007). Genetic evaluation of some yield and yield related traits in wheat. Pakistan J. Biol. Sci. 44: 6-11.

Hajjar R and Hodgkin T (2007). The use of wild relatives in crop improvement: A survey of developments over the last 20 years. Euphytica 156: 1-13.

Hayman BI (1954). The theory and analysis of diallel crosses. Genetics 39: 789-809.

Jinks JL (1954). The analysis of continuous variation in diallel crosses of Nicotiana rustica varieties. Genetics 39: 767-788.

Kashif M and Khaliq I (2003). Mechanism of genetic control of some quantitative traits in bread wheat. Pakistan J. Biol. Sci. 6 : 1586-1590.

Khan AS, Khan MKR and Khan TM (2000). Genetic analysis of plant height, grain yield and other traits in wheat (Triticum aestivum L.). Int. J. Agric. Biol. 2: 129-132.

Khan AS and Habib I (2003). Gene action in a five parent diallel cross of spring wheat (Triticum aestivum L.). Pakistan J. Biol. Sci. 6: 1945-1948.

Khan MQ, Alam K and Chowdhry MA (1992). Diallel cross analysis of some morphological traits in spring wheat. Pakistan J. Biol. Sci. 13: 211-215.

Munir F (1997). Genetic control of some metric traits determine grain yield in bread wheat. M.Sc. (Hons) Agricultural thesis, Department of Plant Breeding and Genetics, University of Agriculture, Faisalabad.

Rabbani G, Munir M, Ajmal SUK, Hassan F et al. (2009). Inheritance of yield attributes in bread wheat under irrigated and rainfed conditions. Sarhad J. Agric. 25: 429-439.

Sharma JC and Ahmad Z (1980). Genetic architecture of some traits in spring wheat. Indian J. Agr. Sci. 50: 457-461.

Shahzad K, Mohy-ud-Din Z, Chowdhry MA and Hussain D (1998). Genetic analysis of some yield traits in wheat (Triticum aestivum L.) Pakistan J. Biol. Sci. 1: 237-240.

Shekhawat US, Bhardwaj RP and Prakash V (2000). Gene action for yield and its components in wheat (Triticum aestivum L.). Indian J. Agr. Res. 34: 176-178.

Steel RGD, Torrie JH and Dickey DA (1997). Principles and procedures of statistics: A Biometrical approach. 3rd edn. McGraw Hill, New York.

Valkoun J (2001). Wheat pre-breeding using wild progenitors. Euphytica 119: 17-23.

Warburton ML, Crossa J, Franco J, Kazi M, et al. (2006). Bringing wild relatives back into the family: Recovering genetic diversity in CIMMYT improved wheat germplasm. Euphytica 149: 289-301. 